Comparative Philosophy Volume 3, No. 1 (2012): 74-85

Open Access / ISSN 2151-6014

www.comparativephilosophy.org

\title{
BENEVOLENT GOVERNMENT NOW
}

\author{
HOWARD J. CURZER
}

\begin{abstract}
Mencian benevolent government intervenes dramatically in many ways in the marketplace in order to secure the material well-being of the population, especially the poor and disadvantaged. Mencius considers this sort of intervention to be appropriate not just occasionally when dealing with natural disasters, but regularly. Furthermore, Mencius recommends shifting from regressive to progressive taxes. He favors reduction of inequality so as to reduce corruption of government by the wealthy, and opposes punishment for people driven to crime by destitution. Mencius thinks government should try to improve the character of the population by preventing or relieving poverty, by setting a good example, and by teaching people to respect and care for each other. He considers a government to be legitimate only if it has the support of the people. His recommended foreign policy is approximately the same as his recommended domestic policy: set a good example and enhance the material wellbeing and moral values of one's own people so that they will enthusiastically support their country, while foreigners will long to immigrate. These are policies of today's left. Mencius was a radical reformer in his own day. His description of benevolent government shows that he is an extreme liberal by contemporary standards, too.
\end{abstract}

Keywords: Mencius, benevolent government, liberal, conservative, regulation, taxation, punishment, legitimacy, civil liberties, foreign policy

\section{INTRODUCTION}

Its emphasis on ritual, filial piety, tradition, hierarchy, etc. raises the specter that the Confucian tradition is inherently politically conservative. ${ }^{1}$ I shall try to assuage this worry, but rather than struggling to encompass the entire Confucian tradition within the bounds of a single paper, I shall focus on Mencius' description of benevolent government for the Warring States period. In this paper, I shall describe the policies and underlying principles of benevolent government in order to compare them with some of the policies and principles currently debated by American liberals and

CURZER, HOWARD J.: Professor, Department of Philosophy, Texas Tech University, USA. Email: howard.curzer@ttu.edu

\footnotetext{
${ }^{1}$ Long $(2003,35-62)$ argues that the Confucian tradition is predominately libertarian.
} 
conservatives. Some ideas which are progressive when first proposed are left behind by the march of history and sound quite reactionary, today. Not Mencius' ideas! Mencius was a radical political reformer in his own day, and perhaps surprisingly, he also turns out to be a liberal - even a radical - by the standards of the contemporary political scene.

Three procedural points: First, contemporary comparisons between Mencian and modern political thought are not lacking, but with few exceptions they have been limited to the ongoing debate about whether human rights are compatible with the Confucian tradition. ${ }^{2}$ Without denying the importance of that debate, I shall frame my discussion in terms of governmental duties. This will have the advantage of being less anachronistic since Mencius, himself, talks of what a ruler should do rather than what people deserve. Discussing duties may better enable us to listen for insight from Mencius rather than arguing about whether Mencian benevolent government meets our standards. Second, I shall extrapolate from the concrete practices Mencius prescribes to the general responsibilities of government which I take to underlie these practices. Although anachronism and misinterpretation are serious risks, such extrapolation is necessary in order to bring Mencius into the contemporary dialog since many of the particular practices he describes are inapplicable to the modern world. Third, in order to keep the focus on Mencius rather than on the details of contemporary politics (and in order to keep this paper to a reasonable length), I shall have to compare Mencian benevolent government to rough caricatures rather than nuanced characterizations of contemporary liberals and conservatives. I ask the reader's indulgence for this oversimplification.

\section{REGULATION AND INTERVENTION}

The Mencius begins with an account of a crucial component of benevolent government. When King Hui takes famine to be a natural disaster to which he responds well, Mencius retorts that famine is a result of a natural disaster (e.g. drought) plus inadequate preparations. He faults the king for merely responding to, rather than forestalling famine (1A3.1-2). The general principle here is that governments should strive to anticipate natural disasters and take steps to avert them. This principle is currently uncontroversial with respect to disasters such as fires and floods, but contested with respect to disasters such as stock market crashes and oil spills. Contemporary conservatives tend to blame crashes and spills on market forces and rock strata. They take crashes and spills to be natural disasters. By contrast, contemporary liberals along with Mencius maintain that crashes and spills are the results of market forces, rock strata, plus inadequate governmental preparation and regulation. ${ }^{3}$ Liberals might take a cue from Mencius. They might supplement their

\footnotetext{
${ }^{2}$ Exceptions include Bai (2008, 19-34), Bell (2006, 231-254), and Chan (2003, 236-253). For a sample of the human rights debate see De Bary and Weiming (1998), Bauer and Bell (1999), and Angle and Svensson (2001).

${ }^{3}$ This dispute is perhaps even more pronounced with respect to problems which are not extreme or sudden enough to qualify as disasters. Conservatives tend to blame nature completely for these
} 
case for more preparation and regulation by citing Mencius' warning that people tend to blame nature for their problems rather than accept the social responsibility to take preventative measures. That is, liberals might use this Mencian nugget of insight about a common blame-shifting mechanism in their debate with conservatives over this issue.

A second issue at the heart of disputes between liberals and conservatives has to do with ways in which other people or institutions might interfere with people's livelihoods. Mencius also has considered view on this issue. For example, a bit later in Mencius' retort to King Hui, Mencius cautions against governmental policies that disrupt people's lives and livelihoods (1A3.3). ${ }^{4}$ Both liberals and conservatives are excruciatingly aware of governments' potential to impose excessive burdens. All acknowledge, in principle, that governments should avoid such intrusions, even if governments are not always successful at avoiding them in practice. Unlike conservatives, however, liberals think that governments are not the only serious threat to people's lives and livelihoods. Liberals also worry about concentrations of private power which enable individuals, corporations, and organizations to restrict and/or exploit others. Liberals believe that an important role of government is to act as a bulwark against such restriction and/or exploitation, even though this protection typically requires governmental restrictions on the freedom of powerful people and groups. As I shall show below, Mencius shares with liberals this worry about threatening concentrations of private power, and his solution also requires governmental curbs on the liberties of the powerful.

Like Confucius, Mencius often moves from one injunction to another which pulls in almost the opposite direction like a sailboat tacking against the wind. In 1A3 he follows his injunction to avoid certain government interventions by tacking in the opposite direction with an injunction to perform governmental interventions of a different sort - in this case by enjoining the king to prohibit extra-fine fishing nets and off-season logging (1A3.3). Mencius' rationale for this prohibition is that if only a few people fish or log excessively, they will gain extra food and fuel, and the overall harm to society will be minimal. Problems arise only when such practices become widespread. Thus, the general principle here is that governments should restrict people's choices in order to prevent a tragedy of the commons. The ongoing struggle over pollution prohibitions shows how controversial this principle is today. Partially because of their faith in the invisible hand, contemporary conservatives balk at the idea that governments should restrict individual freedoms by prohibiting individually profitable acts. As a rhetorical tool, the invisible hand exercises a powerful fascination. Liberals could use some help in breaking its hypnotic hold on people, so they should welcome Mencius' observation that the invisible hand is not

problematic non-disasters, while liberals maintain that it is government's responsibility to prepare for, and respond to these problems. For example, conservatives take terrible traffic problems to be a fact of life while liberals take them to result from a governmental choice to subsidize oil drilling rather than mass transit.

${ }^{4}$ Citations are to Mencius (2008) unless otherwise specified. 
ubiquitous. Although many self-interested choices sometimes produce efficiency, at other times they produce disaster.

Governments must do more than merely refrain from burdensome demands, prepare for disasters, and prevent tragedies of the commons. ${ }^{5}$ According to Mencius, governments must also ensure that crucial tasks get done right. Mencius endorses customs inspections of roads and markets (1B5.3) and the repair of bridges (4B2). More strikingly, Mencius says that governments should regulate and supervise plowing, planting, weeding, reaping, and animal husbandry - every important aspect of farming (1A3.4, 1A5.3, 1A7.21, 1B4.5, 6B7.2). Governments should do this not just occasionally to recoup from disasters, but regularly to increase efficiency. Now farming in the Warring States period was the occupation of the overwhelming majority of the population. Thus, Mencius is not just saying that government must regulate a few aspects of a small, but important sector of the economy; he is saying that government should regulate, in great detail, all aspects of the work of almost everyone. Mencian benevolent government, therefore, is very far from laissez faire government. Presumably, Mencius advocates this drastic policy because he believes that people will not follow expert advice unless required to do so. Current examples of comprehensive regulation and production incentives are numerous, of course, but nowhere near as invasive as Mencius' proposal. Imagine what today's farmers would say if required by the government to plant on certain days, plough in certain ways, etc. On this issue, Mencius seems even further left than contemporary liberals.

\section{CRIME AND PUNISHMENT}

An ideally just policy would convict all and only the guilty. In the real world, liberals opt to err on the side of acquitting some of the guilty in order to minimize convictions of the innocent while conservatives conversely tend to minimize acquittals of the guilty at the cost of convicting some of the innocent. That is, liberals tend to favor various due-process policies while conservatives conversely tend to favor law-andorder policies. Again Mencius takes a liberal view, although this can be obscured by anachronistic expectations (2A2.24). Mencius says that an accused person should be executed only if he or she is judged guilty both by the ruler and by all of the (sophisticated) people (1B7.5). Extrapolating, I suggest that Mencian benevolent government would inflict any severe punishment only if the ruler's representatives (the prosecutors) and the people's representatives (the jury) unanimously agree. This procedure is uncontroversial in the contemporary world, of course. But Mencius is advocating a dramatic modification to the autocratic, harsh procedures of his day.

Studies show that the crime rate generally rises when jobs are scarce and wages are low, ${ }^{6}$ suggesting that some people turn to crime when they cannot find adequate

\footnotetext{
${ }^{5}$ Passage 1A3.3 suggests that governments need do no more than this, but it will become clear that Mencius thinks that considerably more governmental action will be necessary.

${ }^{6}$ Unsurprisingly, this pattern is especially pronounced with respect to property crimes. The statistics are tricky, for this pattern is sometimes masked by other factors.
} 
honest work. ${ }^{7}$ Conservatives claim that people are not forced to become criminals by poverty in capitalist countries, for the free market ensures that opportunities to find honest work are available. Governments need only refrain from interference with the free market. By contrast, liberals believe that governments have obligations to provide a sufficient safety net for the truly needy by providing welfare, food stamps, unemployment compensation, etc. Insofar as governments allow people to become impoverished, liberals are sympathetic to criminals. They tend to blame and punish criminals less than conservatives because they see governments as partially to blame. Again, Mencius is considerably further left than contemporary liberals. Mencius believes not only that destitute people tend to turn to crime, but also and quite remarkably, that when they perform criminal acts, they should not be punished (1A7.20, 3A3.3, 6A7.1). Presumably, the reason is that governments, and not the people, themselves, are responsible for preventing destitution (6B7.2).

\section{NECESSITIES AND LUXURIES}

Mencius claims that the government must provide aid to people directly whenever the people become impoverished. He requires rulers and lesser lords to "distribute grain to those who do not have enough" (1B4.5-10, 6B7.2, 3B9.9). Of course, the government must obtain the grain from those who have more than enough in the first place. One might at first take Mencius to be insisting merely that governments take precautions to ameliorate a disaster's impact by spreading the burden widely rather than allowing it to be wholly born by only a few. He is at least advocating a requirement that everyone participate in a public plan for insurance against starvation. The current dispute over a public plan for healthcare shows how controversial such a requirement is in contemporary America. Liberals generally favor such approaches, conservatives generally oppose them, thinking that insurance should be optional and provided by private companies, instead.

But Mencius is actually making an even more controversial claim. He does not say merely that governments should collect grain in years of plenty, and distribute it in lean years. He is not talking only about spreading the burden of disaster relief; he is also endorsing an ongoing redistributive scheme, a welfare system. He thinks that it would be best if people care for each other voluntarily, but if needy people are not cared for by their relatives and/or friends, then government should be the caregiver of last resort. It should ensure that everyone is cared for (Chan 2003, 236-242).

It might seem controversial to suggest that Mencius think that everyone should be cared for, so let me elaborate. Mencius mentions no benefit-qualification requirement other than need. In particular, he does not exclude those who "do not have enough" because they are inept or lazy farmers, as contemporary conservatives would prefer. Parallel to their view on punishment, contemporary liberals opt to err on the side of supporting some free-riders in order to minimize unsupported truly needy people, while conservatives conversely choose to minimize support for free-riders at the cost

\footnotetext{
${ }^{7}$ For example see Chiricos $(1987,187-212)$ and Weinberg and Mustard (2002, 45-61).
} 
of also depriving some of the truly needy. Mencius takes this to the extreme; he makes no noticeable effort to preclude free-riders at all. Thus, Mencius takes a very liberal stance with respect to distributive, as well as retributive justice. Perhaps Mencius is unaware of the free rider problem, but it seems more likely that he just considers precluding free-riders to be a lower priority than ensuring that help reaches the truly needy.

So far, benevolent government consists in ensuring that the economy runs well and that no one is pushed to the wall or punished when they are so pushed. But Mencius also advocates public musical performances, parks, etc. in order to give the people access to these luxuries $(1 \mathrm{~B} 1,1 \mathrm{~B} 2,1 \mathrm{~B} 4) .{ }^{8}$ Of course it is liberals rather than conservatives who tend to favor public support for the arts, parks, and other luxuries. Mencius goes further. He tells King Hui to take steps to enable fifty-year-olds to wear silk and seventy-year-olds to eat meat (1A3.4, 7A22). In the Warring States period, these were luxuries. So in this passage, Mencius is deploying the liberal principle that government should not only to ensure that people's basic needs are satisfied, and that they have access to certain publicly supported luxuries, but also that each person has his or her own luxuries. ${ }^{9}$ Of course, both liberals and conservatives are committed to the idea that people should have the right to "the pursuit of happiness." But conservatives interpret this right narrowly to mean that people's attempts to increase their happiness should not be interfered with, except insofar as is necessary to protect the rights of others, while liberals interpret the right broadly to mean that people's attempts to increase their happiness should be supplemented by governmental provision of sufficient opportunities. Yet again, Mencius is further to the left than contemporary liberals. He asserts that governments should ensure not just the opportunity to acquire luxuries, but even the luxuries, themselves.

The Mencian safety net is not the same for all. Mencius demands special provisions for those with special needs. To begin with, Mencius says that if the government does its job, "those whose hair has turned gray will not carry loads on the roadways" (1A3.4). That is, Mencius maintains that government is responsible for ensuring that the elderly are able to retire, or at least to avoid heavy labor. This is a sort of social security, a favorite program of contemporary liberals, but not of conservatives.

Moreover, Mencian benevolent government ensures that people have the means to support their living family members and bury their dead ones according to ritual propriety (1A3.3). At first it might seem that Mencius and contemporary conservatives are on the same wavelength here, for both want support and burials to be performed by kinfolk rather than by the government. But the crucial difference comes when people lack kin to support or bury them, or when their kin lack sufficient

\footnotetext{
${ }^{8}$ This is a controversial interpretation of these passages. Mencius may merely be saying that rulers may enjoy these luxuries so long as they ensure that their people have access to other luxuries.

${ }^{9}$ Mencius may be making a similar point when he tells King Xuan to treat the commoners as if they had a "weakness for wealth" (1B5.4). Alternatively, rather than saying that the people should be given luxuries, Mencius may be reiterating his thesis that government should provide a safety net for the impoverished.
} 
resources. In such cases, conservatives are content to leave the matter in private hands; they are willing to wait for some charitable person, church, or NGO to step up to fill the need. By contrast, Mencius considers it to be the responsibility of government to ensure that people are supported and buried. One of Mencius' heroes, King Wen, gave special consideration to four sorts of people: widowers, widows, childless folks, and orphans (1B5.3). Presumably, Mencius thinks that other rulers should do the same, and presumably, the reason is that these are folks with no kin to support or bury them. Thus, if there are no kin, then government should step in. Moreover, if there are kin, but they cannot fulfill their ritual obligations to their family members, it is government that has failed them. Mencius sides with liberals and against conservatives by endorsing the principle that government should enable people to fulfill their obligations to their relatives. A contemporary application of this principle is that needy parents should receive enough welfare and food stamp payments to enable them to support their children.

\section{TAXATION}

How, according to Mencius, is this significant expansion of government to be paid for? Clearly not by increasing the taxes of the common folks. Indeed, Mencian benevolent government involves lowering their taxes (1A5.3). Mencius discusses specific taxes on two groups: merchants and farmers. He proposes the elimination of taxes on merchants' goods, shops, travel, and persons (2A5.2-3, 2A5.5). ${ }^{10}$ Functionally, a tax on goods is a sales tax, for it is passed on directly to the consumer. The other three are equal for poor and rich merchants. Thus, all of these are regressive taxes. Mencius replaces them with a straightforward $10 \%$ income tax (3A3.15). ${ }^{11}$ Again, Mencius sides with contemporary liberals. Liberals are generally in favor of progressive or at least proportional taxes rather than regressive taxes, while conservatives generally wish to lower income taxes and raise alternative taxes such as sales taxes which are regressive.

For the farmers, Mencius recommends the "well-field system." Under that system each household owns a field of a certain size, and in addition contributes 1/8 of the labor necessary to farm a common field of the same size whose proceeds go to the government (1B5.3, 3A3.15). Thus, each farming household gets to keep the proceeds of $8 / 9$ of its labor, and the proceeds of the remaining $1 / 9$ go to the government. If everyone were to pull exactly his or her own weight, each household would be taxed

\footnotetext{
${ }^{10}$ Mencius does believe in taxing merchants when they are not selling goods at a fair price (2B10.7).

${ }^{11}$ In this passage, Mencius distinguishes between those living in the countryside and those in the middle of the state. The former are clearly farmers, and Mencius suggests that they be taxed by "the one-ninth assistance method" which is the well-field system. I think that by contrast the latter must be merchants, and Mencius suggests that they be taxed by "the one-tenth method, making them pay taxes individually."
} 
at the rate of about $11 \% .{ }^{12}$ Functionally however, the well-field system would work a bit differently. I suggest that Mencius favors it because it provides an opportunity for extending benevolence from the family to the neighbors. Generally, the able will feel pressure to contribute more to farming the common field; the less able will be allowed to contribute less. Thus, the well-field system incentivizes benevolence, not by offering tax relief for charitable donations, as contemporary conservatives prefer, but rather by peer pressure on the well-off to contribute more than their $11 \%$ to the government so that the disadvantaged may contribute less than their $11 \%$.

Mencius says that, "benevolent government must begin with setting the field boundaries." Mencius explains that corrupt officials are lax about this because, "If the field boundaries are not straightly set, the well-fields will not be equal, and the grain income will not be even" (3A3.13). Why are corrupt officials indifferent or partial to uneven grain income? Presumably, because those farmers with greater incomes bribe officials to close their eyes to the inequality. Here Mencius is delicately hinting at two morals: inequality is to be avoided, and inequality tends to perpetuate itself or increase because the advantaged are in a position to preserve or increase their advantages. Mencius urges officials to straighten the field boundaries. In other words, he advocates redistribution by taking land from those who have more and giving to those who have less until the land holdings are equalized. Contemporary liberals would not go so far, but they would like to limit inequality, so as to keep the gap between rich and poor from becoming a chasm. Furthermore, it is liberals who fear that concentrations of private power will perpetuate or enhance themselves by corrupting government.

\section{LEGITIMACY}

Mencian benevolent government seems undemocratic. After all, Mencius only discusses monarchies, and he observes that a king may be overthrown only when he has lost the mandate of heaven (1B8, 5A5.1-2), and only by relatives (5B9). ${ }^{13}$ So far this sounds like the divine right of kings, but Mencius also says that rulers who govern improperly should be sacked (1B6). Moreover, it turns out that the mandate of heaven is manifested partially by the people's acceptance of the king (5A5.5-6). Now Mencius is not talking about a majority vote on the king's tenure. Rather his view is that as long as most of the people are not upset enough to revolt, a properly installed king retains heaven's mandate. Even if the overwhelming majority would prefer another ruler, the king retains the mandate so long as the people's preference for an alternative is mild or moderate. This is admittedly far from democratic, although it does show that the people's preferences are relevant.

\footnotetext{
${ }^{12}$ I doubt that Mencius is intentionally advocating a higher tax rate for farmers than for merchants. Rather Mencius seems to be thinking in approximate terms. He takes the well-field system to generate about a $10 \%$ tax rate $(3 \mathrm{~B} 8)$.

${ }^{13}$ Rather than a theoretical limitation, I take Mencius' claim that only relatives may depose a king to be a practical concession; non-relatives shouldn't try because only relatives can get away with it.
} 
The king is one man; almost all governing is done by others. The legitimacy conditions for the king are not the legitimacy conditions for the government as a whole. Retaining the mandate of heaven is not the standard of job security for anyone in government except the ultimate ruler. Everyone in government other than the king must meet a different and higher standard. Mencius says that subordinates should be hired for their worthiness and removed by their superiors for absenteeism, negligence, selfishness, or incompetence (1B6.2, 1B8, 6B7.2). Defending against Mencius' accusation that he hires and fires public officials at whim, King Xuan asks how the competence of a person may be determined. Mencius replies that office holders must meet two conditions; they must be recommended by all of the people and pass a royal examination in order to gain, and to retain office (1B7). Neither the ruler nor the people has complete authority to hire or fire.

Mencius' view of the royal role in hiring might be that the king (or his agents) should interview candidates and/or perform background checks. Presumably, the king should make retention decisions on the basis of "inspection tours" and the "reports on responsibilities" made by subordinates to superiors (1B4.5, 6B7.2). Mencius does not specify a method by which the people might endorse a candidate for office; in particular, he does not specify elections. But he clearly thinks that office holders must have and hold the favor of a large majority of the people. ${ }^{14}$ Thus, Mencian benevolent government is not so different than our own when it comes to determining who should govern. In both cases, a small group of high officials (king, Supreme Court) are insulated from politics by the fact that they are removable only when extremely unpopular, but everyone else in government must gain and retain the endorsement of both the higher-ups in their party and the favor of the majority of the people. Of course, Mencius does not think that everyone is qualified to make policy decisions (3A4.6), but neither do we in the modern world. Rather both we and Mencius think that those who lack the ability to govern should nevertheless have some significant say in choosing officeholders.

\section{CIVIL LIBERTIES}

Mencian benevolent government seems to be at its most conservative when it comes to non-economic liberties and social policy. After all, Mencius rejects liberal neutrality; he hopes to use the power of government to convert the populace to a certain way of life. In particular, he advocates a family-centered, traditional, hierarchical set of values. In both means and ends, Mencian benevolent government seems closer to contemporary conservatives than to liberals.

Yet this turns out to be an illusion. First, liberals are not committed to the idea that the state should be completely neutral. Rather they believe that the state should favor at least the values which are necessary conditions for the possibility of liberal

\footnotetext{
${ }^{14}$ Tiwald distinguishes between two general sorts of popular endorsement: (a) the people's judgments about an official's virtue and qualifications, and (b) their love, loyalty, and political participation under an official. Functionally, these may not be distinct (Tiwald 2008, 277-280).
} 
neutrality. Now the values Mencius hopes to promulgate are pretty general and minimal: "the righteousness of filiality and brotherliness" (1A3.4, 1A7.24). Arguably, these are not values peculiar to just a few particular conceptions of the good, but rather they are necessary bits of a framework which makes it possible for numerous different conceptions of the good to be pursued. That is, they are values that even liberals would consider necessary to inculcate because they make liberal neutrality possible. Rawls, for example, maintains that some of the character traits necessary for the development of the sense of justice are rooted in early filiality (Rawls 1971, 462467; see also Galston 1991, 283-287).

Second, the means Mencius endorses are more liberal than conservative. Mencius' approach is not to legislate morality, as conservatives favor. He takes regulation of behavior to be less effective than teaching which is less effective than modeling good behavior (7A14). Mencius believes that people are inherently good in the sense that their sprouts will develop into virtues so long as basic resources are present and repeated interference is absent (6A8). Thus, rather than urging rulers to ban various practices, Mencius urges rulers to remove restrictions on behavior that might interfere with moral development (1A3.3, 1B2).

Admittedly, Mencius takes education to be important, and he does endorse trying to change people's behavior through teaching in the schools (1A3.4, 1A7.24, 3A4.8). He does not specify a pedagogical strategy, but if he follows Confucius' lead, Mencian teaching would consist of explanation and discussion rather than indoctrination (Analects 2.15).

To summarize, Mencius thinks that government should let people develop naturally with only minimal guidance and limitations. Rather than prohibiting some behaviors, requiring others, and inculcating values by manipulation and/or appeals to authority, benevolent government's main strategies for improving people's values and behavior are to protect people from hardships and interference which would hinder moral development, and to win the people over to virtue by example and reasoned persuasion (4B5, 7A14). Rather than forcing and indoctrinating people, rulers should focus on protecting people from destitution and modeling the right behavior. Overall, benevolent government is not completely neutral, but the values it endorses are arguably socially necessary, and it does not try to impose its values by illiberal means.

\section{FOREIGN POLICY}

Liberals tend to seek lower defense budgets and higher social spending than conservatives. They do not hold the Pollyannaish view that if government can get its domestic policy right, then foreign policy will take care of itself. They allow for wars in cases of defense, narrowly defined, and for wars of liberation to free people from oppressive regimes, although not for wars of conquest or to gain resources. But they do think that economic policy is an important component of national defense. What keeps a state strong is not just its military-industrial complex, but also its social capital, even if the education and well-being of its people cannot be seen to help in 
any direct way. Conservatives tend toward the opposite priorities and policies. They think that reducing the defense budget weakens the country, and increasing social spending does not strengthen it. Mencius too allows for wars of defense and liberation (1B10), but not wars of conquest (2B8.2). But once more Mencius is further to the left than contemporary liberals. His main strategy for protecting a state is to avoid cruelty and enhance the well-being, and thus the loyalty of that state's citizenry through the penal and economic policies describe above. This will win the hearts and minds of the state's own people, making them a formidable force for defense and offense (1A5.3-6, 2B1, 4A9). Moreover, this policy will also win the hearts and minds of the people of neighboring states, making them a resource rather than a threat. If one practices benevolent government, "the people of neighboring states will welcome you like a father or mother.... One will have no enemies in the world" (2A5.6, 3B5.4). Conversely, illiberal penal and economic policy will lose hearts and minds both at home and abroad (1B11, 6B6.4).

Liberals maintain that setting a morally good example is an important aspect of foreign policy. One reason to adopt principled domestic and foreign policies is to deprive other governments of justifications for injustice and oppression. A more positive reason is to give other peoples and governments an actual, rather than ideal model at which to aim. Like liberals, Mencius endorses transforming other governments by example (2A3). Along with advocating a benevolent domestic policy, he opposes compromising with oppressive regimes in order to secure advantages to one's own state (4A7, 4A14.3).

\section{CONCLUSION}

I have not tried to address the actual or potential role of human rights within the whole Confucian tradition. Instead, I have focused on the particular doctrines that constitute Mencian benevolent government. This investigation has shown that Mencius consistently advocates liberal, sometime radical policies and principles. The fact that Mencius is a leftist is one resource that Confucians can use to combat the worry that the Confucian tradition is inherently conservative. And while appealing to the authority of Mencius will not help today's embattled liberals in the West (as appealing to the authority of Jesus seems to help conservatives), liberals can use some Mencian insights and arguments in their struggle for popular opinion.

\section{ACKNOWLEDGEMENTS}

I am grateful to two anonymous referees of Comparative Philosophy for their helpful evaluations and comments on this article. 


\section{REFERENCES}

Angle, S. and Svensson, M. (eds) (2001), The Chinese Human Rights Reader (Armonk, NY: M. E. Sharpe Inc.).

Bauer, J. and Bell, D. (eds) (1999), East Asian Challenge for Human Rights (New York: Cambridge University Press).

Bai, Tongdong (2008), "A Mencian Version of Limited Democracy", Res Publica, 14: $19-34$.

Bell, Daniel (2006), Beyond Liberal Democracy (Princeton: Princeton University Press).

Chan, Joseph (2003), "Giving Priority to the Worst-Off: A Confucian Perspective on Social Welfare", in Bell, D. and Chaibong, H. (ed.), Confucianism for the Modern World, (Cambridge: Cambridge University Press), 236-253.

Chiricos, Theodore (1987), "Rates of Crime and Unemployment: An Analysis of Aggregate Research Evidence", Social Problems, 34: 187-212.

Confucius, Confucius Analects, trans. Edward Slingerland (2003), (Indianapolis: Hackett).

De Bary, T. and Tu, Weiming (eds) (1998), Confucianism and Human Rights (New York: Columbia University Press).

Galston, William (1991), Liberal Purposes (New York: Cambridge University Press).

Long, Roderick (2003), “Austro-Libertarian Themes in Early Confucianism”, Journal of Libertarian Studies, 17(3): 35-62.

Mencius, Mengzi, trans. Brian Van Norden (2008), (Indianapolis: Hackett).

Rawls, John (1971), A Theory of Justice (Cambridge, MA: Harvard University Press).

Tiwald, Justin (2008), “A Right of Rebellion in the Mengzi?”, Dao, 7: 277-280.

Weinberg, Bruce, Gould, Eric, and Mustard, David (2002), "Crime Rates and Local Labor Market Opportunities in the United States: 1979-1997", Review of Economics and Statistics, 84: 45-61. 